\title{
Kajian Komoditas Ekspor Unggulan pada Sektor Industri Pengolahan Jawa Timur dalam Menghadapi RCEP
}

\section{Jodi Rizki Kusuma ${ }^{1 *}$, Achmad Room Fitrianto ${ }^{2}$}

1,2Universitas Islam Negeri Sunan Ampel, Surabaya - Indonesia

\section{A R T I C L E I N F O}

Article history:

Received April, 302021

Received in revised form May, 302021

Accepted June, 82021

Available online June, 28 2021

Kata Kunci:

Industri pengolahan,

komoditas unggulan,

perjanjian RCEP.

Keywords:

Leading commodities, processing industry, RCEP aggrement.

\begin{abstract}
A B S T R A K
Penelitian ini bertujuan untuk menganalisis komoditas unggulan terbaik yang dimiliki oleh sektor industri pengolahan untuk menghadapi perjanjian perdagangan Regional Comprehensive Economic Partnership (RCEP). 15 komoditas berasal dari masing-masing sub sektor industri pengolahan yang merupakan komoditas unggulan dalam perdagangan anggota RCEP, sekaligus menjadikan sebagai variabel penelitian. Sampel variabel berasal dari tahun 2015-2020. Analisis variabel menggunakan data dari BPS Jawa Timur, dan diuji menggunakan uji Two Way ANOVA. Hasil penelitian menunjukan adanya perbedaan yang signifikan dari indeks ekspor masing-masing komoditas unggulan secara keseluruhan maupun spesifik, sekaligus menunjukan komoditas unggulan terbaik dari sisi permintaan pasar internasional negara RCEP. Penelitian menunjukan bahwa keunggulan tertinggi terdapat pada komoditas sub sektor pengolahan hasil mineral (2.74), sedangkan keunggulan terendah pada komoditas sub sektor industri pengolahan tekstil (0.09).
\end{abstract}

\section{A B S T R A C T}

This research aims to analyze the best leading commodities from the processing industry sector to face the Regional Comprehensive Economic Partnership (RCEP) trade agreement. The 15 leading commodities come from each sub-sector of the processing industry which is the leading variable in RCEP member trading, making it a testing variable. Variable samples are from 2015-2020. Variable analysis using data from BPS East Java, and tested using Two Way ANOVA test. The results showed a significant difference from the export index of each leading commodity as a whole as well as specific, while showing the best leading commodities in terms of international market demand RCEP countries. Research shows that the highest advantage is found in the commodity sub-sector of mineral processing (2.74), while the lowest advantage in commodities sub-sector of the textile processing industry $(0.09)$.

\footnotetext{
* Corresponding author.

E-mail : jodirizki22@gmail.com (Jodi Rizki Kusuma)
} 


\section{Pendahuluan}

Kemajuan globalisasi di abad 21 menjadi salah satu momentum bagi setiap negara untuk bisa berkembang dengan segala kemudahan yang diberikan. Negara juga dipacu untuk menjamin keberlangsungan perekonomian negaranya dari kemudahan akses yang ada dan dari persaingan antar negara lain yang mempunyai akses yang sama. Demikian dengan negara berkembang seperti Indonesia, perkembangan globalisasi memaksa Indonesia untuk dipacu mampu beradaptasi dan dapat bertahan di persaingan dunia internasional yang semakin kuat (Nurhayati, 2020)

Persaingan internasional dapat dilakukan oleh setiap negara, Indonesia khususnya mampu menerapkan strategi dalam peningkatan kemampuan di dunia internasional, yaitu untuk merubah sektorsektor terkait menjadi sektor industrialisasi untuk dapat meningkatkan persaingan global dari daerah. Proses industrialisasi sektor tersebut membawa daerah untuk dapat membuat produk yang mempunyai nilai yang lebih, dan pada perkembangan industrialisasi sektor terkait membuat daerah dapat kuat dalam persaingan global dengan produk yang diproduksi, hal tersebut membawa peningkatan ranking Indonesia selama 5 tahun terakhir dari ranking 48 menjadi ranking 32, sebelum turun kembali ke ranking 40.

Komoditas ekspor yang diproduksi oleh sektor industri penting untuk dapat di klarifikasi sebagai produk ekspor unggulan, strategi tersebut dinilai penting untuk mampu bersaing pada pasar internasional. Hal tersebut pernah diteliti oleh Suharsih \& Sriwinarti (2012), subjek penelitian merupakan komoditas ekspor provinsi Yogyakarta, dan menemukan bahwa perdagangan meningkat dari komoditas yang unggul pada provinsi Yogyakarta. Selain itu daerah dapat meningkatkan potensi daya saing mereka dengan menciptakan produk yang mempunyai keunggulan komparatif, serta meningkatkan kualitas produk untuk peningkatan kualitas persaingan di pasar internasional.

Keunggulan yang dimiliki oleh komoditas ekspor selain mampu untuk persaingan global, juga mampu menjadi daya tarik untuk perekonomian daerah, multiplier effect dari komoditas unggulan seperti bahan bakar roda perekonomian, seperti adanya pemberdayaan bahan baku industri, pengambilan bahan baku industri, pengolahan bahan baku menjadi barang jadi dan setengah jadi, dan pendistribusian barang ke konsumen, menjadikan suatu struktur perekonomian yang kekal dan dari komoditas ekspor membuat sebuah daerah dapat berdikari dengan memaksimalkan potensi dan kekuatan daerah mereka (Martadona, \& Leovita, 2019).

Komoditas yang di produksi oleh sektor industri juga membawa peningkatan ekonomi daerah terhadap PDRB (Produk Dosmetik Regional Bruto) mereka. Peningkatan PDRB dari sektor industri pengolahan khususnya, merupakan sebuah nilai tambah bagi daerah yang dihasilkan lewat barang dan jasa yang dihasilkan oleh daerah (Rahman \& Chamelia, 2015). Dominasi nilai tertinggi pada PDRB provinsi Jawa Timur selama enam tahun terakhir, dengan share $42 \%$ dibanding dengan nilai share dari sektor lain, dengan rata-rata nilai sebesar Rp. 430 Miliar (BPS, 2021).

Persaingan global yang semakin ketat membuat negara Indonesia untuk membuat strategi dengan menjalin kerja sama dengan negara-negara tetangga. Menurut penelitian dari Dedi (2017), menemukan bahwa negara harus bersiap untuk menghadapi ketidak menentuan dalam dunia ekonomi dan tuntutan untuk dapat meningkatkan perekonomian negara. Indonesia telah lama dalam menjalani kerja sama internasional antar negara, kerja sama bilateral maupun multilateral telah dilakukan Indonesia dalam bersilahturami dengan sesama negara tetangganya. Indonesia aktif dalam kerja sama internasional pada WTO, OPEC, G20, AFTA, dan kerja sama lain dalam bidang ekonomi, salah satu yang paling besar dalam kaitan nilai ekonomi, penduduk dan investasi yaitu pada perjanjian RCEP (Regional Comprehensive Economic Partnership) yang akan dilaksanakan di tahun 2022.

Perjanjian RCEP meliputi 15 negara, 10 negara anggota ASEAN (Indonesia, Malaysia, Singapura, Filipina, Thailand, Vietnam, Myanmar, Republik Demokratik Rakyat Laos, Kamboja, dan Brunei Darussalam), dan 5 mitra wicara FTA ASEAN (Republik Rakyat Tiongkok, Korea Selatan, Jepang, Australia, dan New Zealand). Dengan potensi pasar pada konsumen sebanyak 2,2 miliar, atau sekitar 30\% konsumen dunia, dengan potensi konsumen sebesar itu dapat menjadi peluang bagi Indonesia dalam peningkatan ekonomi dalam negeri.

Menurut Ragimun (2018), perjanjian RCEP berfokus pada pengurangan hambatan tarif, dan non tarif pada semua perdagangan di antara para pihak. Secara lebih lanjut penetapan tarif tetap berlaku namun di dasari pada liberalasi tarif antar anggota RCEP, dan memulai untuk penghapusan tarif antar anggota RCEP. Dari kebebasan penetapan tarif antar anggota, muncul kesepakatan perdagangan komoditas yang diperdagangkan, kesepakatan tersebut dilakukan negara dalam perjanjian untuk kemudahan perdagangan, meliputi penurunan atau penghapusan tarif bea masuk, kriteria asal barang dan penghapusan hambatan perdagangan non tarif. Kesepakatan perdagangan internasional ini banyak memberikan manfaat bagi kedua belah pihak, apabila kondisi masing masing negara yang menandatangani kerja sama mempunyai tingkat persaingan komoditas yang sama. Melalui berbagai 
kesepakatan perdagangan internasional yang disepakati akan tercipta persaingan yang ketat serta persaingan yang sehat.

Komoditas yang diproduksi oleh industri mempunyai keunggulan dan keunikan masing-masing, hal tersebut bergantung dari jenis dan asal industri yang menghasilkan produk ekspor tersebut, komoditas ekspor di klarifikasi menggunakan Harmonized System (HS) 8 kode sebagai penjelasan secara spesifik terhadap komoditas yang di ekspor, hal tersebut dilakukan karena komoditas yang di ekspor industri Jawa Timur mempunyai jenis dan volume penjualan yang beragam, tidak terkecuali dalam klarifikasi terhadap komoditas unggulan. Beragamnya jenis komoditas ekspor unggulan dari sub sektor industri pengolahan, memunculkan ketidak sistematisan produk komoditas terhadap ekspor yang dilakukan pada negara anggota RCEP, sehingga belum memunculkan rencana kebijakan untuk mengetahui persaingan antar komoditas ekspor, dan menciptakan ketidak maksimalan pada produksi dan arah kebijakan untuk ekspor, yang akan berdampak pada perekonomian daerah (Westphal, 1990). Hal tersebut membutuhkan adanya klarifikasi bagi komoditas unggulan untuk menemukan komoditas terbaik dalam memudahkan langkah kebijakan bagi perjanjian perdagangan RCEP.

\section{Metode}

Penelitian ini menggunakan jenis penelitian kuantitatif deskriptif, dengan jenis data yang digunakan adalah data sekunder komoditas unggulan dari industri pengolahan, dalam kurun waktu 20152020. Pemilihan komoditas unggulan untuk variabel penelitian menggunakan proses purposive sampling yaitu proses seleksi untuk variabel yang akan diteliti, pengambilan syarat variabel penelitian adalah komoditas industri pengolahan yang tercatat pada BPS Jawa Timur dalam kurun waktu 2015-2020; memiliki record ekspor ke negara anggota RCEP; memiliki nilai dan kuantitas terbesar. Dalam proses seleksi ditetapkan 15 komoditas unggulan yang terdiri dari masing-masing sub sektor industri pengolahan, 15 sampel tersebut sekaligus menjadi variabel penelitian.

Saat pengujian mencari komoditas unggulan yang terbaik, akan muncul pertanyaan apakah komoditas unggulan yang diuji memang memiliki keunggulan masing-masing pada ekspor yang dilakukan, sehingga mengindentifikasikan terjadinya perdagangan yang sehat antar komoditas unggulan. Selain itu muncul juga dari pertanyaan sebelumnya apakah masing-masing komoditas unggulan kuat dalam perdagangan internasional, model untuk menjawab masalah tersebut menggunakan model perbandingan uji Two way ANOVA, pengujian pada indeks ekspor, berupa nilai serta kuantitas ekspor komoditas unggulan dalam pengujian perbandingan yang akan dilakukan. Setelah pengujian terhadap perbandingan dari masalah yang akan dibahas, akan dapat dilakukan pengujian mana di antara komoditas unggulan yang terbaik dalam perdagangan RCEP, dengan secara khusus menggunakan model post hoc dengan uji Fisher Least Significant Difference (LSD).

Namun dalam pengujian syarat untuk melakukan pengujian Two way ANOVA, variabel haruslah berasal dari variabel independen, tidak terikat dan tidak terpengaruh dengan variabel lain, variabel juga haruslah berdistribusi normal antar satu sama lain, serta variabel juga haruslah bersifat homogen dengan variabel lain yang akan diuji (Gujarati, 2011).

Pengujian untuk variabel agar memenuhi syarat uji Two way ANOVA adalah pengujian normalitas dengan menggunakan Kolmogorov Smirnov test, penggunaan test tersebut dikarenakan sampel yang diuji lebih dari 50 sampel, dengan mengambil nilai signifikan > 0.05 jika variabel berdistribusi normal. Sedangkan dalam pengujian homogenitas menggunakan Barlett test, penggunaan test tersebut dikarenakan sampel yang akan diuji lebih dari 2 variabel, dengan pengambilan nilai signifikan $>0.05$ jika variabel bersifat homogen. Perumusan untuk pengujian Two way ANOVA dapat diuraikan dengan model sebagai berikut:

$$
\boldsymbol{S S}_{\boldsymbol{G}}=\left(\sum x_{i j}^{2}-\frac{\left(\sum T_{j}\right)^{2}}{n}\right)-\left(\sum \frac{\sum\left(P_{1}\right)^{2}}{r}-\frac{\left(\sum T_{j}\right)^{2}}{n}\right)-\left(\sum \frac{\sum\left(B_{1}\right)^{2}}{t}-\frac{\left(\sum T_{j}\right)^{2}}{n}\right)
$$

Keterangan, SSG sebagai persamaan atau hasil dalam anova; $n$ sebagai jumlah total pengamatan keseluruhan variabel komoditas unggulan; xij sebagai total variabel komoditas unggulan pada kolom yang diteliti \& ulangan variabel komoditas unggulan ke-j; $\mathrm{T}_{\mathrm{j}}$ sebagai jumlah total seluruh perlakuan variabel komoditas unggulan; $r$ sebagai jumlah blok variabel komoditas unggulan; $\mathrm{P}_{1}$ sebagai derajat kebebasan; $\mathrm{t}$ sebagai jumlah perlakuan variabel komoditas unggulan; $\mathrm{B}_{1}$ sebagai rata-rata kuadrat.

Perumusan hipotesis untuk pengujian pada penelitian, dapat dirumuskan sebagai berikut:

a. $H_{0}$ : diduga terdapat perbedaan indeks ekspor pada variabel komoditas unggulan yang ditentukan.

b. $H_{1}$ : diduga tidak terdapat perbedaan indeks ekspor pada variabel komoditas unggulan yang ditentukan. 
Pengambilan hipotesis menggunakan tingkat signifikan dalam uji Two way ANOVA untuk mengetahui perbedaan secara signifikan antar variabel yang di indikasikan lewat indeks ekspor, dengan pengambilan signifikansi perbedaan jika uji menunjukkan $<0.05$, dan $>0.05$ jika variabel tidak menunjukkan perbedaan yang signifikan. Dalam uji lanjut untuk mengetahui perbedaan secara spesifik terhadap variabel komoditas unggulan satu sama lain menggunakan uji post hoc, dengan pengambilan signifikan < 0.05 jika menunjukkan perbedaan yang signifikan, atau > 0.05 jika tidak menunjukan perbedaan yang signifikan secara spesifik dari komoditas unggulan. Pengujian post hoc khususnya menggunakan uji Fisher Least Significant Difference (LSD), pengujian tersebut digunakan sebab dapat menguji secara jelas dengan hasil pasangan rata-rata yang paling berbeda diantara variabel yang diuji, secara jelas akan diketahui komoditas unggulan terbaik dalam ekspor yang dilakukan oleh industri unggulan, dengan digambarkan pada mean grafik pengujian.

\section{Hasil dan pembahasan}

Penelitian ini menggunakan data komoditas ekspor unggulan industri pengolahan Jawa Timur tahun 2015 hingga 2020. Komoditas ekspor unggulan diukur dari besarnya nilai komoditas yang diekspor, serta banyaknya komoditas yang diekspor ke negara anggota RCEP. Dari purposive sampling yang telah dilakukan, diambil 15 komoditas ekspor dengan kriteria yang ditentukan, dan semua variabel berasal dari masing-masing sub sektor industri pengolahan. Penetapan tahun pengambilan untuk data merupakan salah satu spekulasi pada masa pemerintahan presiden yang bertugas, hal ini menandakan peran kebijakan serta gaya pemerintahan seorang presiden yang berpengaruh terhadap lini perekonomian negara maupun daerah (Nickelsburg \& Norpoth, 2000). Komoditas ekspor unggulan dari tahun 2015 hingga 2020 mengalami fluktuasi dari masing-masing nilai serta kuantitas ekspor, hal ini dipengaruhi permintaan negara yang mengimpor komoditas unggulan tersebut.

\section{Penentuan status komoditas ekspor unggulan}

Penentuan status komoditas ekspor merupakan salah satu tanda apakah komoditas mempunyai ciri-ciri terhadap spekulasi dari masalah yang telah dirumuskan sebelumnya. Dari spekulasi tersebut akan dijabarkan dalam menandakan apakah terdapat kesamaan kesempatan komoditas unggulan dalam ekspor yang dilakukan, pengujian pada variabel nilai serta kuantitas di indikasikan pada indeks ekspor.

Tabel 1. Hasil uji normalitas (Kolmogorov-Smirnov test)

\begin{tabular}{cccc}
\hline Variabel & $\mathrm{p}$ & Sig. & Ket. \\
\hline $\begin{array}{c}\text { Komoditas ekspor } \\
\text { Unggulan }\end{array}$ & 0.315 & 0.064 & $\begin{array}{c}\text { Distribusi } \\
\text { normal }\end{array}$ \\
\hline Sumber: data olahan dari peneliti & &
\end{tabular}

Penentuan normalitas data untuk variabel indeks komoditas ekspor menggambarkan apakah variabel data memang mewakili terhadap komoditas unggulan dalam ekspor pada negara anggota RCEP, sehingga memudahkan kerangka dalam analisis pengujian. Hasil pengujian pada variabel indeks komoditas ekspor unggulan menunjukkan normalitas pada distribusi data. Ditunjukkan dari tabel 2, terlihat bahwa variabel indeks ekspor menunjukkan sig. 0.064, menunjukkan subtansi normalitas data $0.064>0.05$, sehingga data variabel indeks ekspor memang menggambarkan perdagangan untuk komoditas unggulan, selain itu syarat untuk normalitas data terpenuhi.

Tabel 2. Hasil uji homogenitas (Barlett test)

\begin{tabular}{cccc}
\hline Variabel & F & Sig. & Ket. \\
\hline $\begin{array}{c}\text { Komoditas ekspor } \\
\text { Unggulan }\end{array}$ & 528.772 & 0.281 & Homogen \\
\hline $\begin{array}{l}\text { Sumber: data olahan dari peneliti } \\
\text { Sum }\end{array}$
\end{tabular}

Sumber: data olahan dari peneliti 
Penentuan homogenitas data untuk variabel indeks ekspor bertujuan dalam pengujian apakah komoditas unggulan mempunyai kesamaan ekualitas pada ekspor yang dilakukan, serta menguji apakah data komoditas unggulan merupakan sekumpulan data yang berasal dari populasi industri pengolahan yang homogen, selain itu pada pengujian kesamaan variabel terhadap indeks ekspor menjadikan variabel lebih valid dan akurat. Dari Tabel 3 terlihat bahwa variabel indeks ekspor dengan menunjukkan sig. 0.281, menunjukkan subtansi homogenitas data $0.281>0.05$, sehingga menunjukkan ekspor yang dilakukan memiliki kesamaan variabel (homogen).

Dalam syarat terakhir dalam pengujian perbandingan, yaitu mengenai independensi data. Dalam kaitannya terhadap komoditas ekspor unggulan sektor industri pengolahan merupakan variabel data yang independen, hal tersebut disebabkan data nilai serta kuantitas yang tetap tanpa adanya pengaruh dari komoditas lain, hal tersebut menjelaskan bahwa variabel indeks pada komoditas ekspor unggulan dapat berdiri sendiri, sehingga pengujian perbandingan dapat dilakukan.

\section{Status komoditas unggulan pada ekspor negara RCEP}

Tabel 3. Hasil hipotesis (uji Two Way ANOVA)

\begin{tabular}{ccccccc}
\hline Source & Sum Squares & Df & Mean Square & F & Sig. & Ket. \\
\hline Nilai Komoditas & 2530336,000 & 14 & 18078345,00 & 26.221 & 0.000 & \\
Kuantitas Komoditas & 254831,081 & 1 & 2548317,10 & 3.697 & 0.046 & Signifikan \\
$\begin{array}{c}\text { Nilai Komoditas*Kuantitas } \\
\text { Komoditas }\end{array}$ & 198328,191 & 14 & 1390123,20 & 5.291 & 0.031 & \\
\hline
\end{tabular}

Sumber: data olahan dari peneliti

Pengujian untuk menjawab rumusan pertanyaan, apakah komoditas unggulan memiliki keunggulan masing-masing pada ekspor yang dilakukan, sehingga mampu di indentifikasikan terjadinya perdagangan yang sehat antar komoditas unggulan, serta apakah masing-masing komoditas unggulan kuat dalam perdagangan internasional. Menggunakan pengujian Two Way Anova untuk dapat menjawab, hasil analisis perbandingan komoditas ekspor unggulan ditunjukan dalam Tabel 4, hasil analisis perbandingan dimana pengambilan signifikan $<0.05$, menemukan terdapat perbedaan signifikan pada nilai, kuantitas, serta indeks ekspor pada komoditas unggulan. Dari variabel nilai komoditas menunjukkan sig. $0.00<0.05$, lalu pada variabel kuantitas komoditas menunjukkan sig. $0.046<0.05$, dan pada indeks komoditas menunjukkan sig. $0.031<0.05$. Hasil pengujian tersebut juga mengidentifikasi bahwa indeks komoditas ekspor pada hipotesis pertama $\mathrm{H}_{0}$ diterima, sedangkan hipotesis kedua $\mathrm{H}_{1}$ ditolak.

Perbedaan yang signifikan dari nilai, kuantitas serta indeks komoditas unggulan memperlihatkan terjadinya perbedaan terhadap keunggulan dari masing-masing komoditas unggulan yang melakukan ekspor pada anggota RCEP, pernyataan tersebut juga dapat menandakan perdagangan yang sehat antar komoditas ekspor unggulan pada sektor industri pengolahan. Dari hasil pengujian tersebut dapat di indikasikan bahwa masing-masing komoditas unggulan mempunyai kekuatan yang berbeda dalam perdagangan internasional, sehingga terindikasi bahwa masing-masing komoditas unggulan kuat bagi perdagangan internasional pada negara anggota RCEP. Penetapan dan pengujian yang telah dilakukan merupakan rangkaian penelitian untuk dapat mengetahui variabel komoditas terbaik bagi perdagangan RCEP.

Tabel 4. Hasil hipotesis secara spesifik (uji Fisher Least Significant Difference)

\begin{tabular}{ccc}
\hline (I) komoditas & $\begin{array}{c}\text { Mean difference } \\
\text { komoditas } \\
\text { unggulan (I-J) }\end{array}$ & $\begin{array}{c}\text { Mean } \\
\text { Sig. }\end{array}$ \\
\hline $\begin{array}{c}\text { Whiteleg shrimps (Litopenaeus vannamei) } \\
\text { Liquid fractions of refined palm oil in packing of 25kg }\end{array}$ & $-2,00206 \mathrm{E}+12$ & 0.026 \\
Other Cigarettes containing tobacco & $-2,07474 \mathrm{E}+12$ & 0.047 \\
Crude petroleum oils & $-1,62932 \mathrm{E}+12$ & 0.05 \\
Lysine \& its esters; made of salt thereof & $1,3696 \mathrm{E}+12$ & 0.000 \\
\end{tabular}


TSNR 20, other, standard indonesian rubber

Other whole hide \& skin of bovine, in other form

Other Non-coniferous of tropical wood

Wrapped cigarette tow of man-made fibres

Other footwear, covering the ankle

Articles of jewellery of precious metal

Refined copper for cathodes and sections of cathodes

Wiring harness for motor vehicle, used for vehicles

Vehicle Parts; Road Wheels And Parts And Accessories

Other wooden furniture, for kitchen or bedroom use

$\begin{array}{ccc}\text { Komoditas } & -1,4015 \mathrm{E}+12 & 0.046 \\ \text { unggulan } & -9,72414 \mathrm{E}+11 & 0.043 \\ \text { lainnya } & -6,91612 \mathrm{E}+11 & 0.039 \\ & -2,32292 \mathrm{E}+12 & 0.045 \\ & -2,22401 \mathrm{E}+12 & 0.073 \\ & 3,43965 \mathrm{E}+12 & 0.021 \\ & 2,63064 \mathrm{E}+12 & 0.032 \\ & -1,12321 \mathrm{E}+12 & 0.031 \\ & -1,3432 \mathrm{E}+12 & 0.042 \\ & -2,12847 \mathrm{E}+12 & 0.054\end{array}$

Sumber: data olahan dari peneliti

Pada uji lanjut post hoc dapat diketahui dari masing-masing komoditas ekspor unggulan mempunyai signifikansi perbedaan dengan komoditas ekspor unggulan yang lain, diketahui hampir semua komoditas unggulan mempunyai perbedaan yang signifikan dengan hasil sig. $<0.05$, namun pada komoditas unggulan footwear other covering the ankle dan wooden furniture for kitchen or bedroom use tidak menunjukkan perbedaan yang signifikan, diketahui dari hasil sig. > 0.05, dapat dianalisiskan bahwa kedua komoditas unggulan tersebut tidak memiliki keunggulan yang berbeda dari komoditas unggulan lainnya, namun dalam mean square terlihat nilai yang cukup besar jika dibandingkan nilai mean komoditas lain.

Pengujian yang dilakukan mampu untuk mengambil analisis yang dapat dijelaskan yaitu dari beberapa komoditas unggulan mempunyai keunggulan yang berbeda-beda terhadap komoditas ekspor unggulan yang lain, dan pada kedua komoditas unggulan yang tidak berpengaruh signifikan, mampu dilihat pada mean square hasil pengujian. Hal tersebut mampu untuk mengidentifikasi perbedaan keunggulan dari masing-masing sub sektor industri ditinjau dari plots mean dengan menggunakan mean square, sehingga di indikasikan dapat dilakukannya sistem perankingan untuk mencari komoditas unggulan terbaik dalam perdagangan anggota RCEP.

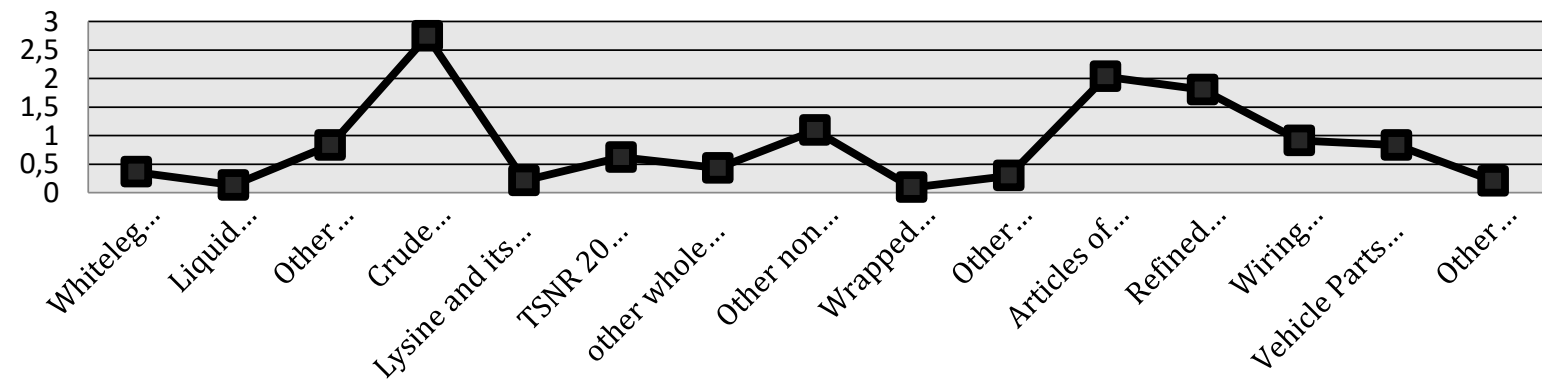

Grafik 1. Peringkat dengan grafik plots mean komoditas unggulan Sumber: data olahan dari peneliti

Analisis hasil pengujian pada sistem pemeringkatan komoditas unggulan dapat teringkas pada Grafik 1, pemeringkatan ini sekaligus mengindikasikan komoditas terbaik secara berurutan, secara spesifik penjelasan pada ranking pertama adalah komoditas Crude petroleum oil dengan nilai 2.74, ranking kedua adalah komoditas Articles of jewellery of precious metal dengan nilai 2.03, ranking ketiga pada komoditas Refined copper for cathodes and sections of cathodes dengan nilai 1.81, ranking keempat adalah komoditas Other non coniferous of tropical wood dengan nilai 1.09, pada ranking kelima komoditas Wiring harnesses for motor vehicles dengan nilai 0.91, ranking keenam adalah komoditas Vehicle Parts; Road Wheels And Parts And Accessories Thereof dengan nilai 0.84, ranking ketujuh pada Other cigarettes containing tobacco dengan nilai 0.83, ranking kedelapan pada komoditas Whiteleg shrimps; with head and tail dengan nilai 0.83, ranking kesembilan pada komoditas TSNR 20, other, standard indonesian rubber dengan nilai 0.62 , ranking kesepuluh pada komoditas Other whole hide \& skin of bovine, in other form dengan nilai 0.43 , ranking kesebelas pada komoditas Other footwear, covering the ankle, made platform of wood dengan nilai 0.29, ranking kedua belas adalah komoditas Lysine \& its esters; made of salt thereof dengan nilai 0.21, ranking ketiga belas adalah komoditas Other wooden furniture; for kitchen or bedroom 
use dengan nilai 0.20 , pada ranking keempat belas pada komoditas Liquid fractions of refined palm oil dengan nilai 0.13 , dan terakhir pada ranking kelima belas pada komoditas the wrapped cigarette tow of man-made fibres dengan nilai 0.09 .

Ranking pertama sampai ke lima belas mengidentifikasikan komoditas unggulan terbaik industri pengolahan dari provinsi Jawa Timur untuk perdagangan RCEP. Dua dari tiga komoditas unggulan terbaik merupakan komoditas barang setengah jadi, hal tersebut selaras dari penelitian Barigozzi, et. al (2010) yang mengindenfikasikan bahwa perdagangan internasional masih didominasi dari komoditas barang ekspor mentah serta setengah jadi. Selain itu diketahui juga dominasi dari hampir seluruh ranking merupakan komoditas pendukung bagi komoditas lain pada negara tujuan ekspor, hal tersebut menimbulkan terjadinya korelasi kepentingan dan keuntungan bagi kedua negara yang melakukan perdagangan.

Sistem perangkingan dari pengujian yang telah dilakukan juga mengindikasikan bahwa hampir kesemua ranking merupakan komoditas barang setengah jadi, namun hal tersebut patut menjadi perhatian bahwa masih dapat dikembangkan potensi dari komoditas unggulan terkait, menjadi komoditas barang jadi, hal tersebut selaras dengan penelitian dari penelitian Guan \& Ma (2003), Ficko, et. al (2005), Changjun, dan Hua (2002), serta Singh (2009), bahwa transisi perubahan komoditas barang setengah jadi menjadi komoditas barang jadi mampu meningkatkan perekonomian dalam negeri, hal tersebut didukung dari kemudahan berdagang antar negara bersangkutan, namun masih dalam masa transisi negara dapat melakukan ekspor pada komoditas setengah jadi sebelum peningkatan ekspor pada komoditas barang jadi, faktor tersebut merupakan rekomendasi peneliti bagi negara yang ingin memulainya. Pengambilan kebijakan yang tepat dari pemerintah daerah serta pihak industri terkait diharapkan untuk dapat mampu menjawab kesempatan dagang internasional dalam rangka menghadapi perdagangan RCEP di tahun 2022.

\section{Simpulan dan saran}

Berdasarkan hasil penelitian menunjukkan bahwa terjadi perbedaan yang signifikan dengan nilai sig. $0.031<0.05$ pada tinjauan indeks ekspor antar komoditas unggulan, hal tersebut berimplikasi bahwa komoditas unggulan memiliki keunggulan masing-masing pada ekspor yang dilakukan, sehingga mampu di indentifikasikan terjadinya perdagangan yang sehat antar komoditas unggulan, serta masing-masing komoditas unggulan terindikasi kuat dalam perdagangan internasional.

Pada pengujian secara lebih spesifik, di indikasikan bahwa hampir semua komoditas unggulan mempunyai perbedaan keunggulan bagi komoditas lain. Namun pada komoditas komoditas unggulan footwear other covering the ankle dan wooden furniture for kitchen or bedroom use menunjukkan nilai sig. $>0.05$, di indikasikan bahwa kedua komoditas unggulan tersebut tidak mempunyai keunggulan yang berbeda terhadap komoditas unggulan yang lain.

Pada sistem perangkingan di indikasikan secara berurutan sebagai komoditas terbaik, terindikasikan dari pengujian secara berurutan dengan nilai sebagai berikut; komoditas Crude petroleum oil (2.74), komoditas Articles of jewellery of precious metal (2.03), komoditas Refined copper for cathodes and sections of cathodes (1.81), komoditas Other non coniferous of tropical wood (1.09), komoditas Wiring harnesses for motor vehicles (0.91), komoditas Vehicle Parts; Road Wheels And Parts And Accessories Thereof (0.84), Other cigarettes containing tobacco (0.83), pada komoditas Whiteleg shrimps; with head and tail (0.83), komoditas TSNR 20, other, standard indonesian rubber (0.62), komoditas Other whole hide \& skin of bovine, in other form (0.43), komoditas Other footwear, covering the ankle, made platform of wood (0.29), komoditas Lysine \& its esters; made of salt thereof (0.21), komoditas Other wooden furniture; for kitchen or bedroom use (0.20), komoditas Liquid fractions of refined palm oil dengan nilai (0.13), komoditas the wrapped cigarette tow of man-made fibres (0.09).

Peningkatan kemampuan ekspor diharapkan mampu dilakukan oleh daerah sebab kebanyakan rangking terbaik komoditas ekspor masih merupakan komoditas barang setengah jadi, peralihan transisi untuk mampu melakukan ekspor barang jadi sebagai peningkatan nilai ekspor dengan masih melakukan ekspor komoditas barang setengah jadi, hal tersebut diharapkan mampu dilakukan oleh daerah untuk memanfaatkan perdagangan bebas RCEP di tahun 2022.

Penelitian ini masih terbatas pada komoditas unggulan dari masing-masing sub sektor industri pengolahan, pada penelitian ini juga terlihat ketimpangan kemampuan dari masing-masing sub sektor industri pengolahan dalam perdagangan pada negara anggota RCEP, dan secara spesifik belum melihat kemampuan sub sektor industri pengolahan dari komoditas lain yang telah diekspor. Sangat disarankan pada penelitian selanjutnya diharapkan untuk dapat menguji dan menganalisis kemampuan dari setiap sub sektor industri pengolahan. 


\section{Daftar Rujukan}

Barigozzi, M., et, al. (2010). Multinetwork of international trade: A commodity-specific analysis. Physical Review E-Statistical, Nonlinear, and Soft Matter Physics, 81(4), 1-23. https://doi.org/10.1103/PhysRevE.81.046104

BPS. (2021). PDRB Berdasarkan Lapangan Usaha provinsi Jawa Timur. BPS Indonesia, Jakarta.

Changjun, Y. \& Hue. P. (2002). Does comparative advantage explains export patterns in China? China Economic Review, 68(1), 275.

Dedi, P. (2017). Kepentingan Indonesia Dalam Menggagas Perundingan Regional Comprehensive Economy Partnership. Jom FISIP, 4(1), 68-70.

Ficko, M., et. al. (2005). Prediction of total manufacturing costs for stamping tool on the basis of CAD-model of finished product. Journal of Materials Processing Technology, 164-165, pp. 1327-1335. https://doi.org/10.1016/j.jmatprotec.2005.02.013

Guan, J., \& Ma, N. (2003). Innovative capability and export performance of Chinese firms. Technovation, 23(9), 737-747. https://doi.org/10.1016/S0166-4972(02)00013-5

Gujarati. (2011). ECONOMETRICS. Palgrave Macmillan Publisher, New York.

Martadona, I., \& Leovita, A. (2019). Peranan Komoditas Unggulan Tanaman Pangan Terhadap Pembangunan Ekonomi Wilayah Propinsi Sumatera Barat. TATA LOKA JOURNAL, 21, 328-334.

Nickelsburg, M., \& Norpoth, H. (2000). Commander-in-chief or chief economist?, The president in the eye of the public. Electoral Studies, 19(2-3), 313-332. https://doi.org/10.1016/S0261-3794(99)00054-2.

Nurhayati, D. (2020). Strategi Indonesia Dalam Menghadapi Tantangan Global Dibidang Ekonomi. Jurnal Yudharta, 33-48.

Ragimun. (2018). Kerja Sama Perdagangan Barang Pada Forum Rcep Bagi Indonesia. Jurnal Ekonomi \& Kebijakan Publik, 9(1), 67-81.

Rahman, Y. A., \& Chamelia, A. L. (2015). Faktor - Faktor Yang Mempengaruhi Pdrb Kabupaten / Kota Jawa Tengah Tahun 2008-2012. Jejak, 8(1), 88-99. https://doi.org/10.15294/jejak.v8i1.3857

Singh, D. A. (2009). Export Performance of Emerging Market Firms. International Business Review, 18(4), 321-330. https://doi.org/10.1016/j.ibusrev.2009.03.002

Suharsih, S., \& Sriwinarti, A. (2012). Daya Saing Produk Ekspor Di Era Perdagangan Bebas. Jurnal Ekonomi Dan Studi Pembangunan, 13(1), 1-11.

Westphal, L. E. (1990). Industrial Policy in an Export-Propelled Economy: Lessons from South Korea's Experience. Journal of Economic Perspectives, 4(3), 41-59. https://doi.org/10.1257/jep.4.3.41 